Historic, Archive Document

Do not assume content reflects current scientific knowledge, policies, or practices. 

THE COTTAGE GARDEM $S$

LAMSIMG $\sim$ MICHIGAT

国

Michigan's Modern Horticultural Establishment; Headquarters: Just beyond city limits on W. St. Joseph street, with entrance also on W. Main street (U. S, 27). TELEPHONE 29021. \&ึ/f GROWN IN YOUR OWN CLIMATE AND GROWN WELL,
CONSCIENTIOUS ADVICE IN

GARDENIN

MATTERS

Business Hours:

March 15-June 1, from 6:30 A. M.-8:30

P. M., Saturdays, 5:30 P. M.

Closed Sunduys except hy appointment.

$\$$

Landscape Department

We are equipped to build Pleasure

Gardens of highly Modern Design.

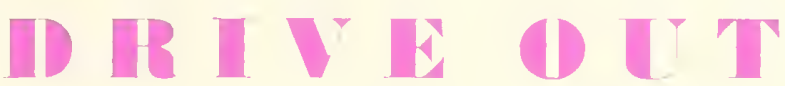

and see the Acres and Acres of Modern Varieties of EVERGREENS, SHRUBS, TREES, PERENNIALS, ROCK. PLANTS, Etc.

\section{FIRESIII, IDUG}

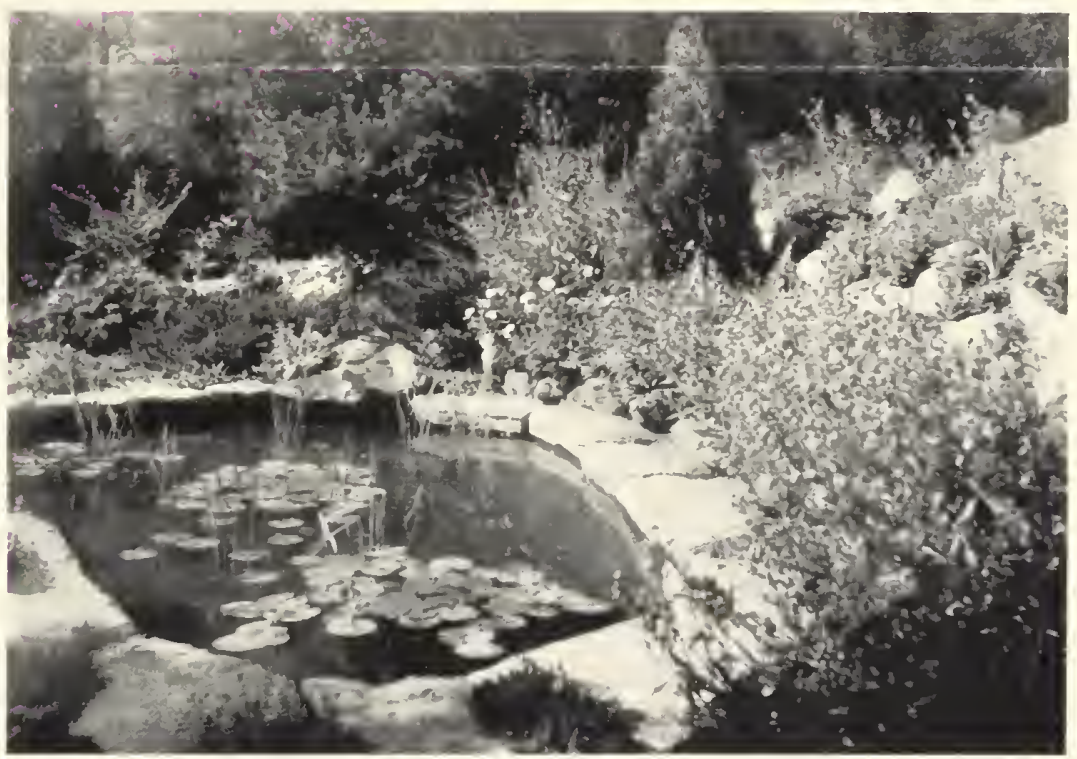

A Corner in Sample Rock Garden at Cottage Gardens

THE SALESGROUND AT OUR NURSERY

For your convenience we have arranged a Salesground where every variety we offer is represented. This makes it unnecessary to go through the Fields. 

W We have always made it a point to keep our collections of Plant Material up-to-date
and in many cases "ahead of the general trade." Whenever there is something new you can, as a rule, find it at Cottage Gardens.

In this folder we are drawing your attention to some of the finer things that you may have wanted for many years.

\section{DADUNE CNEORUM (Garland Hlower)}

A Dwarf Shrub for Rockery, massed in front of Evergreens, Shrubs, or along the garden path. In May and August literally covered with lovely rose-pink blossoms, radiating the delightful Daphne fragrance. Strong field-grown plants, B x B*, $\$ 1.50$ each. Extra heavy plants, $\mathrm{B} \times \mathrm{B}^{*}, \$ 2.00$ each.

\section{JADANESE FIOWERING CHERTIES}

Those who have seen the Japanese Cherries at Washington, D. C., will be delighted to be able to get these marvelous plants grown right in the heart of Michigan. We propagate Japanese Flowering Cherries in quantity; they are absolutely hardy. We offer herewith the four leading varieties:

HISAKURA, double. Deep pink, foliage purplish, 3-4' plants, $\$ 2.75$ each.

KOFUGEN, double. Deep pink, vigorous upright-growing, $3-4^{\prime}$ plants, $\$ 2.75$ each.

SHIROFUGEN, large, double. Light pink flowers, $2-2 \frac{1}{2} \mathbf{2}^{\prime}$ plants, $\$ 1.50$ each

$3^{\prime}$ plants, $\$ 1.75$. $3-4^{\prime}$ plants, $\$ 2.25$.

ROSEA FLORA PLENA, light, double. Rose pink, gorgeous bloomer plants, $\$ 2.00$ each.

\section{MAGNOIIA SOULANGEANA}

Immense White Flowers, purplish inside, blooming in early spring. Balled and Burlapped specimen: $3-4^{\prime} \mathrm{B} \times \mathrm{B}^{*}, \$ 12.00$ each; 4-5', $\$ 18.00$ each. 5-6', \$35.00 each. $6-8^{\prime}, \$ 45.00$ each. MUST BE ORDERED EARLY.

\section{CIINIESE FIOWIEING CRAB ADDIES}

Put "new blood" into your garden by planting some of these fine Flowering Crab Apples. Either planted alone or in groups they are beautiful; their bright fruit in the fall enriches birdlife. List of 26 varieties sent upon request. We list below the most popular kinds: ATROSANGUINEA. Fine lawn specimen. Covered with single crimson blossoms in spring, $\$ 1.25$ each.

BECHTEL'S CRAB, large, double. Pink blossoms like roses, $\$ 1.25$ each.

ELEYI. NEW. Purple-leaved, large deep magenta blossoms, \$1.25 each.

NIEDZWETZKYANA. Purple leaf and bloom; large flowers, $\$ 1.00$ each.

SCHEIDECKERI. Literally covered with lovely double pink blossoms, early, $\$ 1.00$ each.

\section{SCARLET HA WTHORN}

Paul's Scarlet. Most popular of all Hawthorns, double scarlet flowers and red berries in the fall: $3-4^{\prime}$ plants, $\$ 1.50$ each.

\section{FRENCH IILACS}

One of our specialties of which we possess a collection of over 40 varieties, including the latest originated by Mr. Lemoine of France. We are listing below a short list. (Complete list may be had upon request.) Plants offered are sturdy $21 / 2-3$, bushy plants, properly grown.

ALEX. VON HUMBOLDT, double, red-purple

Each

BELLE De NANCY, double, satiny rose

BUFFON, single, mauve-pink...

CHARLES TENTH, single, lilac, free-blooming

CHARLES JOLY, double, bright crimson-violet, midseason...

CLAUDE BERNARD, semi-double, bright lilac

EDOUARD ANDRE, double, clear rose

FRENCH GIANT, large single white

JEAN MACE, double, bluish mauve.

LAMARTINE, single, large mauve-pink. Fast growing and free-blooming. Early

LOUVOIS, voluminous clusters of large single flowers, deep violet purple with bluish shade.

MME. ANTOINE BUCHNER, double, tender rose, shaded mauve; buds rich carmine rose opening to a distinct blue

MME. CASIMIR PERIER, double, cream-white

MME. LEMOINE, double white, very large

MARIE LEGRAYE, single, white.

MONT BLANC, large, single white

PASCAL, single, typical lilac

PRESIDENT GREVY, double blue

PRESIDENT LOUBET, double, reddish-purple.

SOUVENIR DE LOUIS SPAETH, single, deep purplish violet, large trusses

$\$ 1.25$

1.50

2.00

1.50

1.75

2.00

2.00

2.00

1.50

1.50

1.75 
A rare article, grown at Cottage Gardens. Fine varieties of French Lilacs, grown on $3 \mathrm{ft}$. stems, ideal for formal gardens or in between shrub groups. Prices range from $\$ 2.50$ each to $\$ 6.00$, according to variety. List will be sent upon request or we suggest driving out and seeing them.

\section{MAHONIA AQUIFOLA (Holly-Ieaved Mahomia)}

This plant can again be imported into Michigan. Leaves come out a fresh green, tinted purple and in autumn assume beautiful tints of red and bronze, which are retained throughout winter. Small yellow flowers in May. MUST BE ORDERED EARLY. 11/2-2' plants, $\$ 2.25$ each. P $\mathrm{x} \mathrm{B}^{* *}$.

\section{IADANESE FIOWIRING QUINCE (Tylomia Daponia:a)}

Fine for hedges or shrub groups, bright scarlet blossoms in early spring. $2-3^{\prime}$ plants, $\$ 0.50$ each; $\$ 5.00$ per dozen.

\section{HARDY CHRYSANTHEMUMS}

In the FARLY and LARGE-FLOWERING Varieties.

We do not know of any more gorgeous fall-flowering Perennial than the up-to-date varieties of Hardy Chrysanthemums. For years we have grown the newer early-flowering Chrysanthemums and customers have been delighted with the results from our plants. You cannot plant too many of this splendir] plant as they bloom when most other perennials are through. The flowers are ideal for cutting and planted in mass against Evergreens or Shrubs their beauty cannot be surpassed. All plants $25 \mathrm{c}$ each, $\$ 2.50$ per dozen, $\$ 15.00$ per 100 .

A. BARHAM. Leautiful orange-brome. Larly. Large double hlooms,

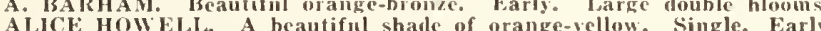

and free-blooming.

la Sovisle, Deep mauve-pinh.

CARRIE: (Syn. Glory of Seven ()aks). Beautiful large deep zellow

MAYLLLEN. Cerise-pink

flowers.

CHAMPAIGN. Bright ruby-red.

DOROTHY. Warly snow-white. vigorous.

IDOLF. Salmon-pink. Bloous first weeh in Octoher.

MURILL(). Best pink of all the hardy ehrysanthemums, although

b.ooming a little later than some of the others.

ASIVA. A wealth of white hloom about Oetober Ist.

IMNETKA, l'ure white.

TELLOW NORUANDIE. A hronze sellow. Farly atul free-flowering.

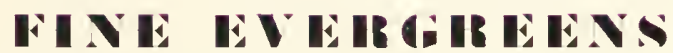

The beautiful Evergreens you see on your trips east you can obtain at Cottage Gardens in various sizes. We have a considerable planting of that marvelous new Blue Juniper MEYERI, which is so beautiful in the rock garlen. In our Salesground you find some of each variety so you do not have to go through the fields to see the different sorts.

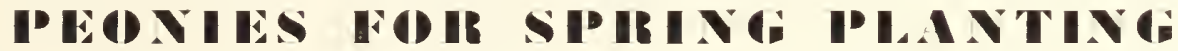

Besicles an extensive list of varieties, we offer: One plant each, RED, PINK and WHITE, total \$1.25. Separate, each, 35 cents.

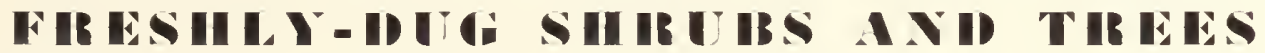

In up-to-date varieties. Visit our nurseries where you will find acres of these for your inspection.

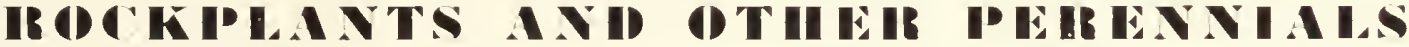

In our Salesground you will find a large collection of Rock Plants and Perennials that are planted so that you can select the plants you want and get them dug right there.

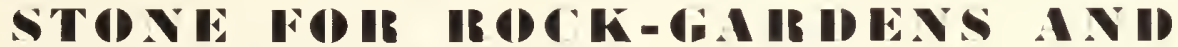 STEIPING STONE}

We cary in stock Wisconsin Lime Stone, Ohio and Wisconsin Tufa, limestone flagging, Michigan moisture-absorbing stone.

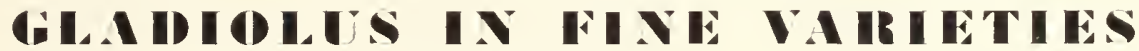

Top-size Bulbs in the standard and new varieties.

\section{ID III I I I S}

Countess of Lonsdale, Apricot, 35c; Sagamore, golden orange-buff, 75c; Mrs. Ida Ver Warner, mauve-pink, 50c; Jersey's Beauty, true-pink, $75 \mathrm{c}$; Jack Rose, bright carmine-red, $35 \mathrm{c}$; Jean Kerr, pure white, $50 \mathrm{c}$ each.

\section{SIP ECIAI. I IB IS I IF FEIR}

Rainbow collection of beautiful Fleur-de-Lis, 10 plants, every one different, at $\$ 1.00$. (Good until our spring stock is exhausted.)

\section{COTTA GE GA IB IE IS LA WN SEEID}

We started mixing lawn seed several years ago and customers told us that they never had been able to buy such wonderful seed. Still our mixture is no secret, only we are mighty particular that the seed is always fresh and free from chaff and other impurities. 


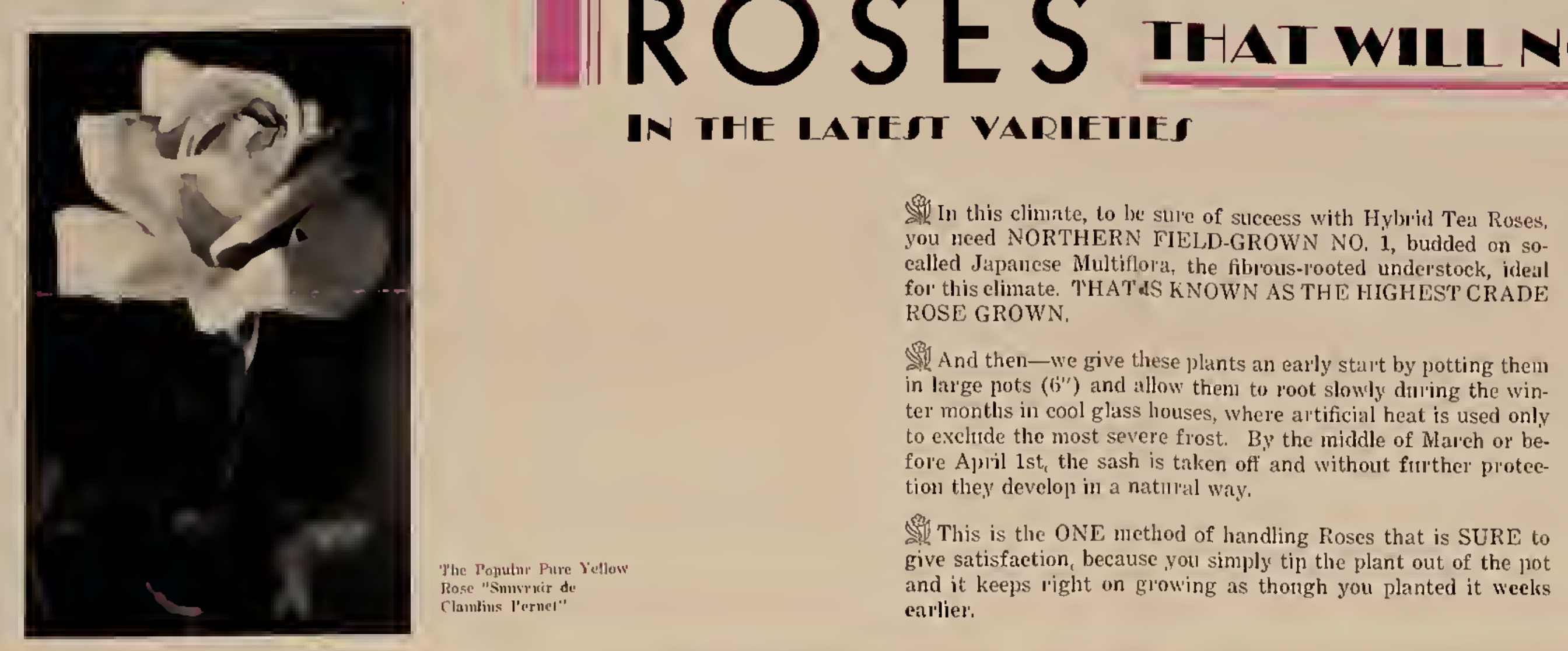

92 PRE-FERTILIZED. Fol every 100 Roses we pot, we nse one lin'ge wheelbar'row of well-decayed cow nanure, which is another chundance of flawer's almost from the time you plant theme

Tor' eight yen's now we have been handling Roses this way and the increase in onr Rose sales proves that our efforts to deliver the highest quality is appreelated. Last fall we again increased our facilities and offer this spring a glorious collection of the most Modern Rose

Of of course, taking the highest grade Rose grown and then give it snch care as we do, makes the price a little higher', but then and so our Roses are not only far' superior' but also far more and so our Roses are not only far' silperior, but also far more

HY BDID TEA ROSES (Hloom from Early Simmer till Frost)

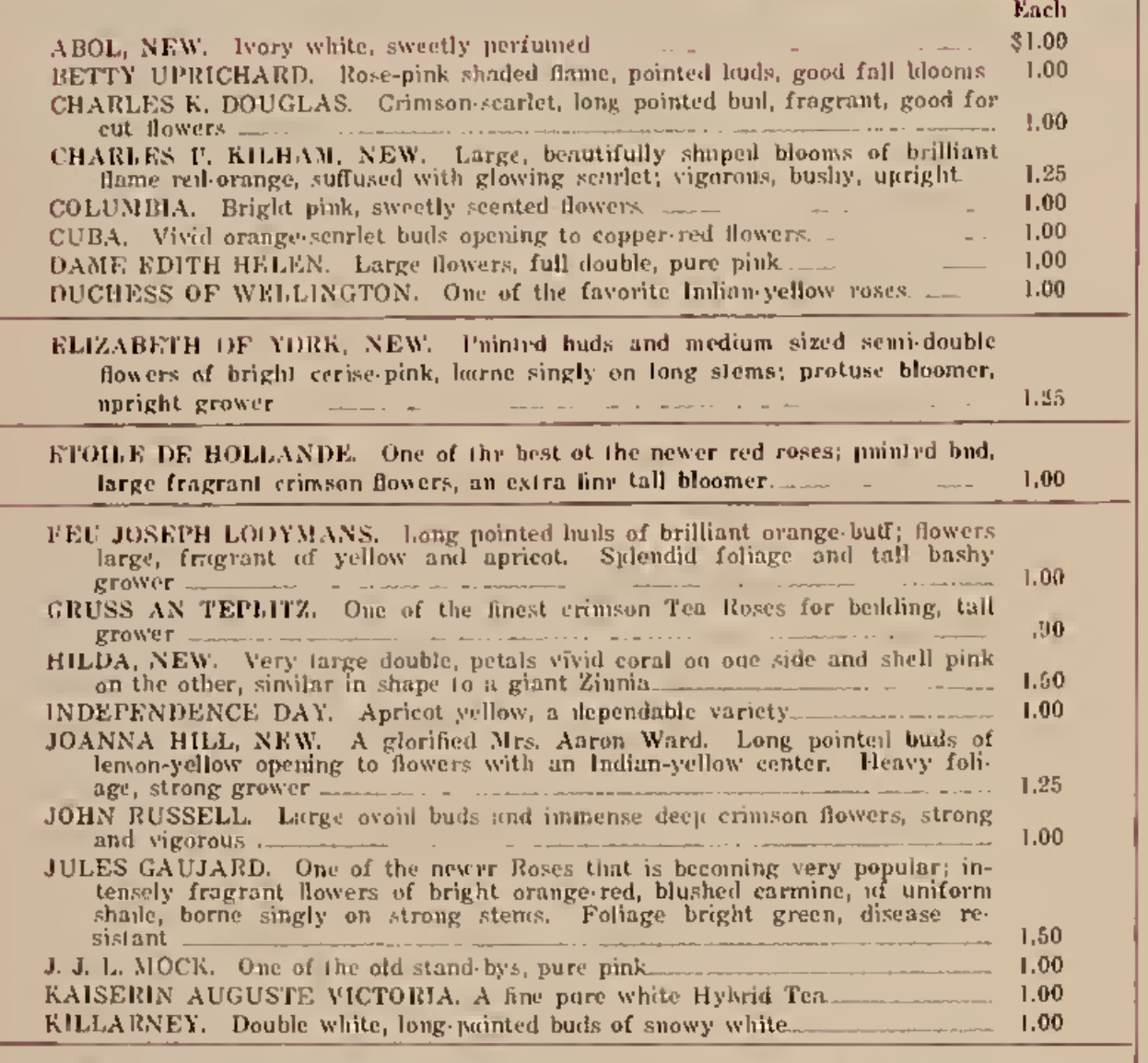

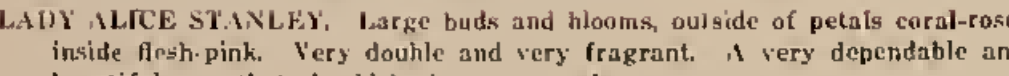

THE FDIENDIY DOIYANTHA (Or Miniature: IBOSES) (Note the New varielies)

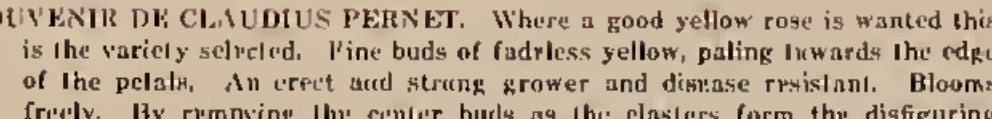

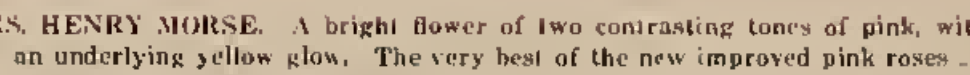

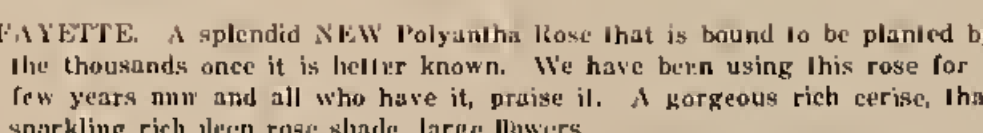

\section{HADDY CIIMBING ROSES}

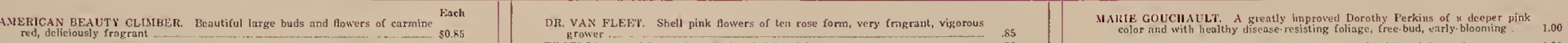

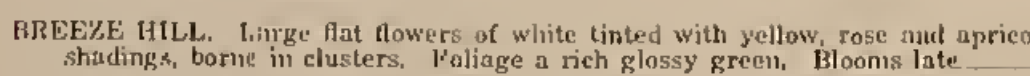

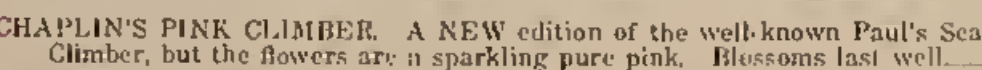

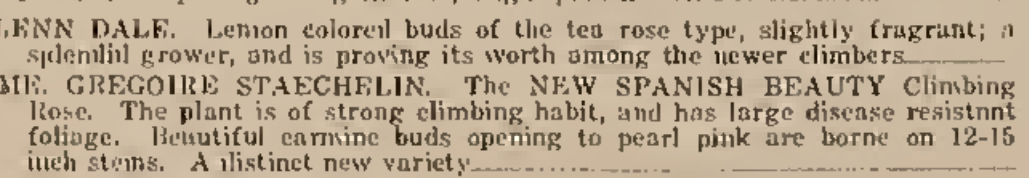

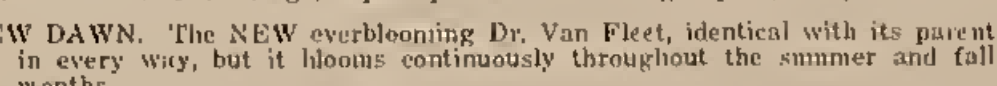

in every wily,

TWO MARVEIOUS EVERTIOOMHNG SHTUR ROSES

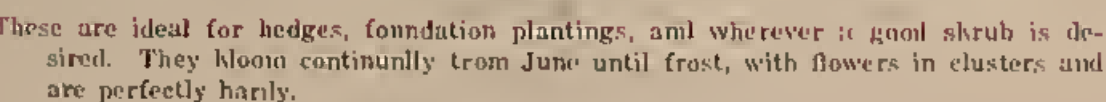

\section{MISCEILANEOUS ROSES}

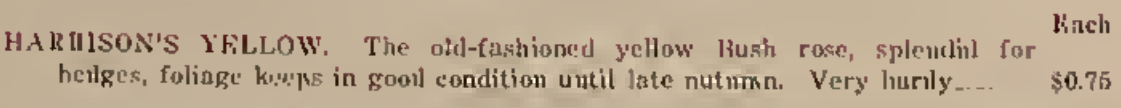

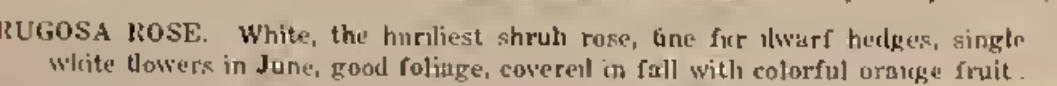

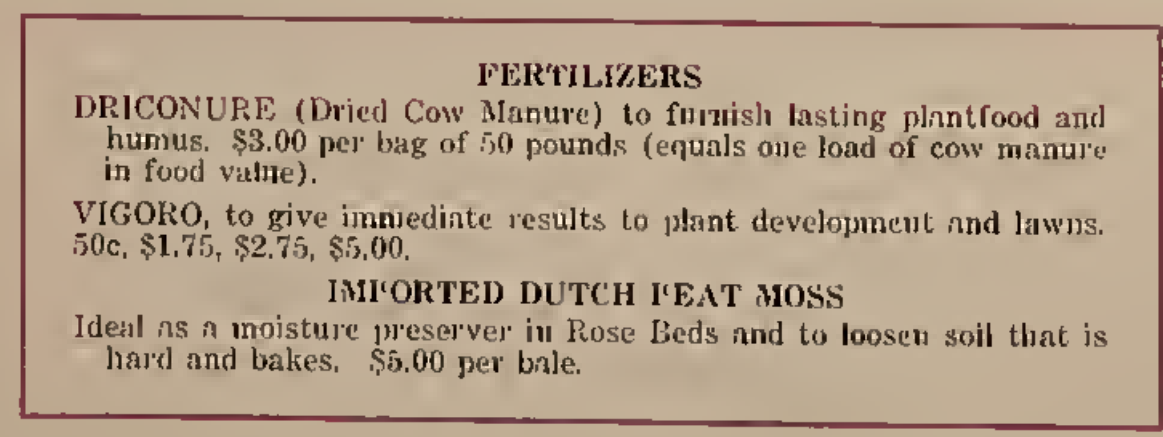

ONE PROPERLY' HANDLED-VIGOROUS P'LANT-DIRECT FROM THE NURSERY' IS WORTH MORE THAN ANY PAY FOR IT 


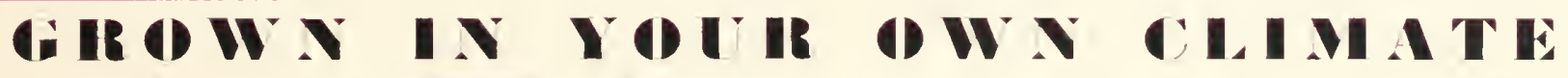 AND GIAOWN WELL.
}

\author{
THOLSINDS OF FINE EVERGREENS \\ ORNAMENTAL SIIRLBS \\ TREES, VINES. ROSES, PERENYIIIS \\ ROCKPLINTS \\ 'TO SELEC'T FROM
}

\section{...VISIT US ...}

\section{Up-To-Date Varieties}

\section{Freshly IDug}

\section{Prices Within IReason}




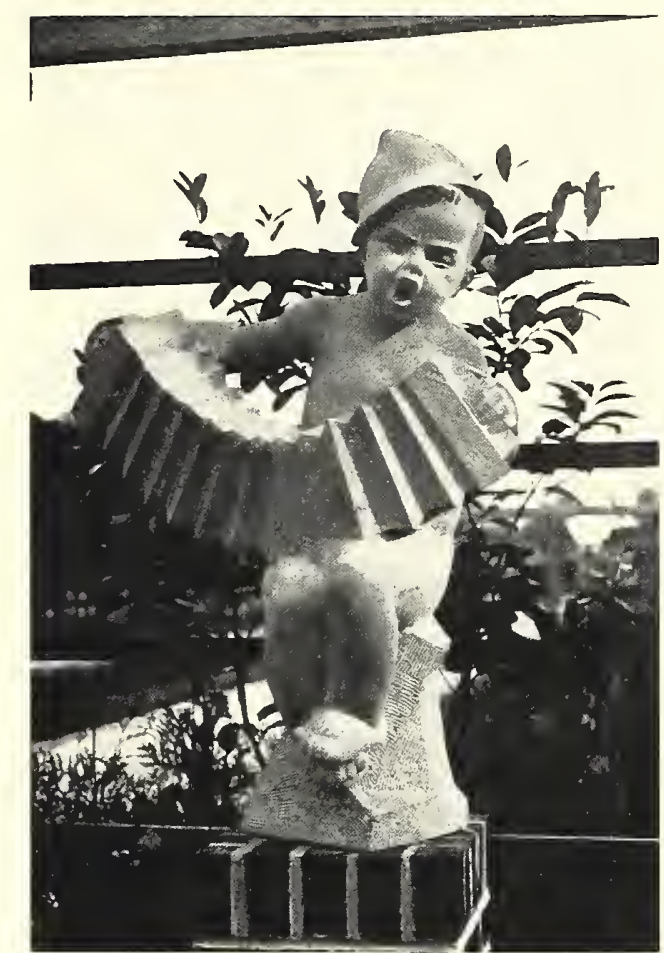

Srulpture by Edmund Meusel
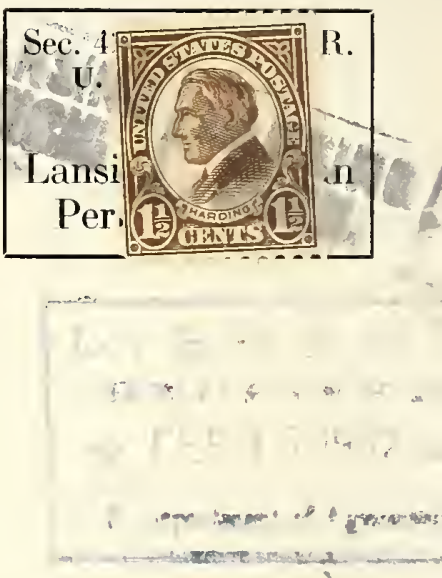

U. S. Department of AGRiculture,

WAShington, D. C.

Bureau of Plant Industry BUREAU OF PLANT INDUSTRY
Iforticultural Crops and Diseases $8-3591$ 